\title{
Corrigendum to "Existence, blow-up and exponential decay estimates for a system of nonlinear wave equations with nonlinear boundary conditions" [Math Meth Appl Sci. 37 (4) (2014) 464-487. https://doi.org/10.1002/mma.2803]
}

Le Thi Phuong Ngoc ${ }^{1}$ and Nguyen Thanh Long ${ }^{2}$

${ }^{1}$ University of Khanh Hoa

${ }^{2}$ University of Natural Science, Vietnam National University Ho Chi Minh City

September 21, 2020

\begin{abstract}
This note presents corrections to our paper [1]. We also give remarks and additions related to other papers [2]-[15].

\section{Hosted file}

MMA-2020-09-16-002.pdf available at https://authorea.com/users/360592/articles/482223corrigendum-to-existence-blow-up-and-exponential-decay-estimates-for-a-system-ofnonlinear-wave-equations-with-nonlinear-boundary-conditions-math-meth-appl-sci-37-42014-464-487-https-doi-org-10-1002-mma-2803
\end{abstract}

\section{Hosted file}

MMA-2020-09-16-002.tex available at https://authorea.com/users/360592/articles/482223corrigendum-to-existence-blow-up-and-exponential-decay-estimates-for-a-system-ofnonlinear-wave-equations-with-nonlinear-boundary-conditions-math-meth-appl-sci-37-42014-464-487-https-doi-org-10-1002-mma-2803 